\title{
THE MONSARÁS DISTRICT COMMUNITY ON THE ISLAND OF MARAJÓ: ITS AFFINITY WITH ARTISANAL FISHING AND THE ENVIRONMENT
}

\section{${ }^{* 1}$ Wagner Davy Lucas Barreto, ${ }^{2}$ Nelson Wellausen Dias, ${ }^{3}$ Lidianne Pereira Gomes Lucas Barreto, ${ }^{4}$ Gustavo Nogueira Dias, ${ }^{5}$ Vanessa Mayara Souza Pamplona, ${ }^{6}$ Ademir Ferreira Silva Junior, ${ }^{7}$ Carlos Augusto Cordeiro Costa and ${ }^{8}$ Eldilene da Silva Barbosa}

\begin{abstract}
${ }_{1}^{1}$ Master Professor, at Federal College Tenente Rêgo Barros; Souza; CEP 68447-000, Belém, Pará, Brazil; 2PhD Professor at the University of Taubaté (SP), Avenida Nove de Julho, 245, CEP 12020-200 Taubaté; Sao Paulo; Brazil; ${ }^{3}$ Master, Technical Activity Center (CAT); Av. Almirante Barroso 5274, Castanheira, Belém Pará, Brazil; CEP 66645 250; ' Doctor Professor at Federal College Tenente Rêgo Barros, Souza; CEP 68447-000, Belém, Pará, Brazil; 5PhD Professor at the Rural University of the Amazon, Campus Paragominas, Highway PA 256, Km 6, S / N, Nova Conquista, Paragominas, - (PA) - Brazil; ${ }^{6} \mathrm{PhD}$ Professor at the Federal University of Pará, Address: Rua Coronel José Porfírio 2515- Esplanada do Xingu, CEP 68372-040, Altamira - (PA) -Brazil; ${ }^{7} \mathrm{PhD}$ Professor at the Federal Rural University of the Amazon; Belém, Terra Firme; Pará, Brazil CEP 66077-830; 8Master Professor at the Federal Rural University of the Amazon; Terra Firme, Belém, Pará, Brazil. CEP 66077-830
\end{abstract}

\section{ARTICLE INFO}

Article History:

Received $17^{\text {th }}$ March, 2020

Received in revised form

$11^{\text {th }}$ April, 2020

Accepted $03^{\text {rd }}$ May, 2020

Published online $30^{\text {th }}$ June, 2020

\section{Key Words:}

Community, Amazon,

Fishing Closure Insurance.

*Corresponding author:

Wagner Davy Lucas Barreto

\begin{abstract}
Artisanal fishing is an activity of great importance in Brazil and the Amazon, mainly for the generation of income and source of subsistence. The objective of this research is to characterize the artisanal fisheries of the Monsaráscommunity on Ilha do Marajó and to identify the relationships between these activities and factors related to the environment. The methodology was based on the application of a questionnaire to artisanal fishermen in this community and to carry out local observations. The results show that fishing in Monsarás is carried out throughout the year, from Monday to Friday and can last 6, 12 and even 24 hours a day. The species of greatest value and the most caught are the yellow hake (Cynoscionacoupa) and the golden hake (Brachyplatystomarousseauxii). Labor relations take place through the partnership system and the production of fish is traded in the community itself or to a middleman who works at the place that resells the fish, mainly in the Ver-o-peso market in Belém. Environmental laws known in Monsarás are those related to compliance with the rules of the closed season. Artisanal fishing is characterized by an activity that requires few fishing gear, small vessels and that cause low environmental impact.
\end{abstract}

Copyright (C) 2020, Wagner Davy Lucas Barreto et al. This is an open access article distributed under the Creative Commons Attribution License, which permits unrestricted use, distribution, and reproduction in any medium, provided the original work is properly cited.

Citation: Wagner Davy Lucas Barreto, Nelson Wellausen Dias, Lidianne Pereira Gomes Lucas Barreto et al. "The monsarás district community on the island of marajó: its affinity with artisanal fishing and the environment”, International Journal of Development Research, 10, (06), 37333-37337.

\section{INTRODUCTION}

Artisanal fishing is an activity of great importance in Brazil, as it assumes a socioeconomic function, occupation of labor, income generation and food supply for the population, mainly along the entire coast and in the country's inland waters (ABREL et al., 2020; SANTOS, 2005). This type of fishing is practiced by different types of oil, with small or medium-sized wooden boats and by family labor (CAJADO; MEIRELES; CASIMIRO FILHO, 2020; ISAAC et al., 2006).
According to Nogueira (2005), artisanal fishermen are those who use instruments and techniques appropriate to environmental conditions, such as: hand-line, longline, mesh and other fishing gear. They carry out this activity all year round with their families and companions in order to meet their basic food needs and income generation. In Monsarás, district of the municipality of Salvaterra, on the island of Marajó-PA, the main professional and economic activity of the population is artisanal fishing. Fishermen use one or more types of fishing gear to catch fish in order to catch one or more species. In Monsarás, as in other regions of the State, fishing 
depends directly on the capacity of natural replenishment of the fishing stock, so it is an activity closely related to the environment, which determines, for example, the times and periods when fishing should take place throughout the year. In Marajó Island, fishing activity follows an annual harvest and off-season calendar. The rainy months in the region mark the off-season when fishermen carry out their practices in the rivers close to the community due to the Law of the Closed. When the rains were over, usually in the month of May, the capture of the main crop begins, a period in which the capture of the fish is done by means of canoes and boats that collect tons of fish in order to serve as food and source of income for the fishermen by supplying the regional fish market (NOGUEIRA, 2005). In view of this scenario, the objective of this research is to characterize the artisanal fisheries of the Monsarás community in Marajó Island and to identify the relationships between these activities and factors related to the environment.

\section{DATA ANALYSIS}

The results obtained were analyzed based on descriptive statistics. The data were processed using Microsoft $\AA$ Excel ${ }^{\circledR}$ software version 2016, graphs with total and percentage values expressed and discussed using updated literature. The researchers' records, made through observation and the logbook, were important to complement the analysis. river Amazonas to the west (MIRANDA, 2010). The municipality of Salvaterra hasanestimatedpopulationof 20,183 people, according to the IBGE Census (2010), wholive in an area of $1,039 \mathrm{~km} 2$. This municipality is located in the Marajó mesoregion and Arari microregion, which includes the Lago do Arari basin. It consists of five districts, Condeixa, Jubim, Joanes, Monsarás and Salvaterra Sede. Its boundaries are the municipality of Soure to the north, the Bay of Marajó to the east and south and the municipality of Cachoeira do Arari to the west and south (IBGE, 2010; SEPOF, 2011) as shown in Figure 1. Access to the island region is by fluvial sea and is done by large vessels (ships) or ferries that depart from the Port of Belém or Icoaraci and dock at the Port of Camará, in the municipality of Salvaterra.

The seat of the municipality is $78.1 \mathrm{~km}$ from the capital Belém. Internal access to the island is done by land, as is the case of the District of Monsarás. The island of Marajó is characterized by a hot and humid tropical climate, with an average annual temperature of $27^{\circ} \mathrm{C}$. According to Koppen's classification, the island has two climatic units, the first has a humid tropical climate and an average monthly rainfall of 60 $\mathrm{mm}$, and the second, a humid tropical monsoon climate and excessive precipitation in some months. The rainiest period occurs between the months of December and June and the least rainy between July and November. The relative humidity of the air is high throughout the year, varying from $81 \%$ to $92 \%$ (MIRANDA, 2010).

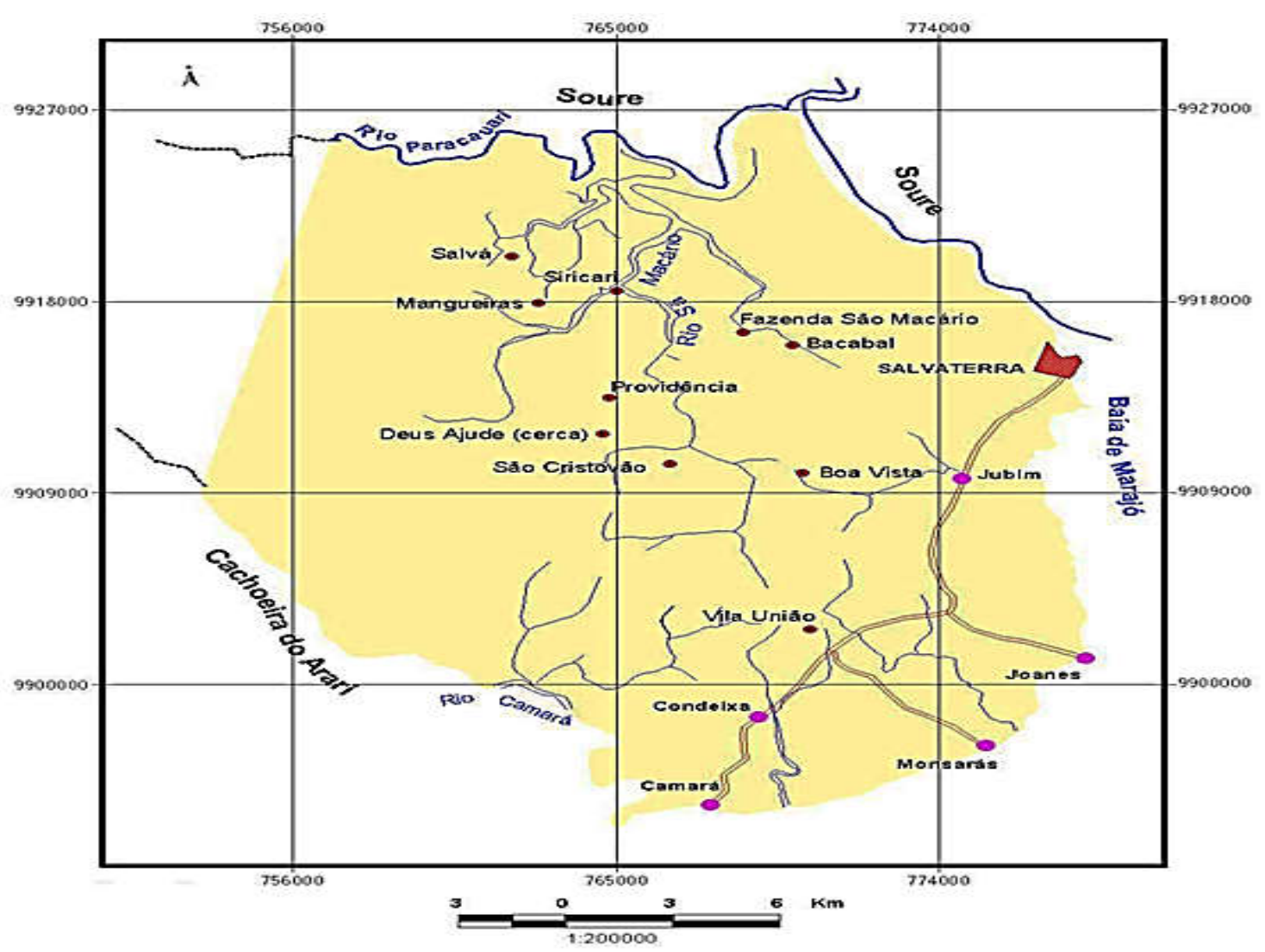

Source: Modified from NOGUEIRA (2005)

Figure 1. Geographical location of the municipality of Salvaterra. Marajó Island - PA

\section{MATERIAL AND METHODS}

The island of Marajó belongs to the archipelago of Marajó, in the extreme north of the State of Pará. With an area of 49,000 $\mathrm{km} 2$, the island is bounded by the Atlantic Ocean to the north, the Pará River to the south, the Marajó Bay to the east and the
Methodological Procedure: This research started with a documentary analysis of other works dealing with artisanal fishing in the region itself and in its surroundings. During field activities, for example, the mapping of a typical maritime fluvial path of a fisherman in the community was carried out using a GPS navigation receiver. This made it possible to 
identify the areas where fishermen usually catch fish. From the coordinates obtained in the field, a map was drawn up that illustrates the path traveled (Figure 2). In this route, the fisherman covered a total of $12.2 \mathrm{~km}$. The starting point (1) has coordinates with latitude $0{ }^{\circ} 56$ '20 "south and longitude $48^{\circ} 34^{\prime} 23^{\prime \prime}$ west and indicates the location of the berth (wharf) built in the Monsarás stream from which the canoes and small boats depart and medium size to fish in Marajó Bay. The capture point (2) is located $2.70 \mathrm{~km}$ from the coast and 5 $\mathrm{km}$ in a straight line from the berth in waters that reach $19 \mathrm{~m}$ in depth, according to the nautical chart used. It should be noted that the point of capture was determined in the month of July, a period in which the fish is usually closer to the coast.

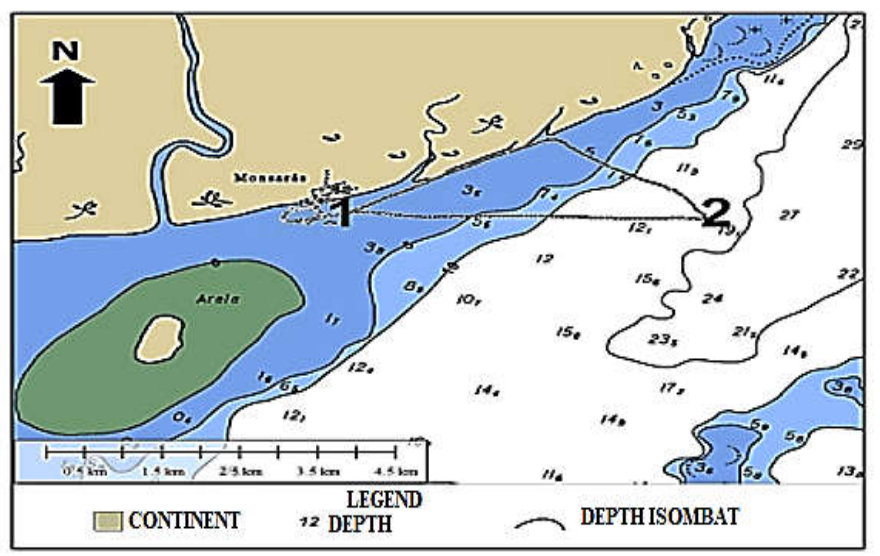

Figure 2. Maritime fluvial path to the catch area

According to the IBGE (2010), in the district of Monsarás, in its urban portion, 417 inhabitants live, of which 105 are economically responsible for supporting their families and, of these, $72 \%$ are male. The main subsistence activity of Monsarás residents is artisanal fishing, in which 60 fishermen have been identified who perform this activity daily. In order to characterize this community of artisanal fishermen, a questionnaire was applied to fishermen, which was developed based on models applied in other surveys that also aimed at characterizing artisanal fishing in artisanal fisheries communities (Arnaud, 2008; Nogueira, 2005; Gomes et al., 2009). In total, 40 questionnaires were answered, representing $66.7 \%$ of the fishermen in the community. The questions in the questionnaire sought to obtain information about: personal characteristics (number of children, education and housing); professional characteristics (monthly income, time working with fishing and exercising other paid activity); characteristics of the fishing activity (type of fishing modality, fish of the highest value caught, etc.); socioeconomic information (contribution to the INSS, time of colonization, receipt of Defeso Insurance, etc.). In addition to specific questions about fisheries (travel frequency, fish production per trip, fish conservation); vessel characteristic (type of boat used, maximum amount of fish, etc.); and knowledge of environmental aspects (perceived changes in the environment, change in the size of the fish, the closed season, environmental laws related to the activity). The interviews were carried out randomly throughout the sampling period, carried out at the fish landing sites, in the wharves (places where the boats leave), inside the boats and, in some cases, at the fishermen's homes. Observations and photographic records were also made in order to better characterize the socioeconomic context of the community and complement the information obtained from the questionnaires.

\section{RESULTADOS E DISCUSSÃO}

Artisanal fishing is developed throughout the year and its schedule follows its own dynamic marked by the natural cycle. Fishermen's work and rest hours are established as a result of the ebb and flow of the tides that are different each day (PEIXOTO, 2010). Peixoto's statement (2010) reflects the reality of most of the fishermen of Monsarás. Figure 3A shows that $72.5 \%$ fishermen fish 20 days / month (from Monday to Friday), of which $82.8 \%$ have fishing as their main source of income. $17.5 \%$ fishermen who work 15 days a month and the $10.0 \%$ who work 12 days / month are fishermen who carry out other activities (Figure 3A). Just over half of the fishermen work 12 hours a day, the $7.5 \%$ fishermen who work six hours a day fish in small canoes and the $10.0 \%$ who spend 24 hours at sea have larger vessels and equipment for fish conservation (Figure 3B).

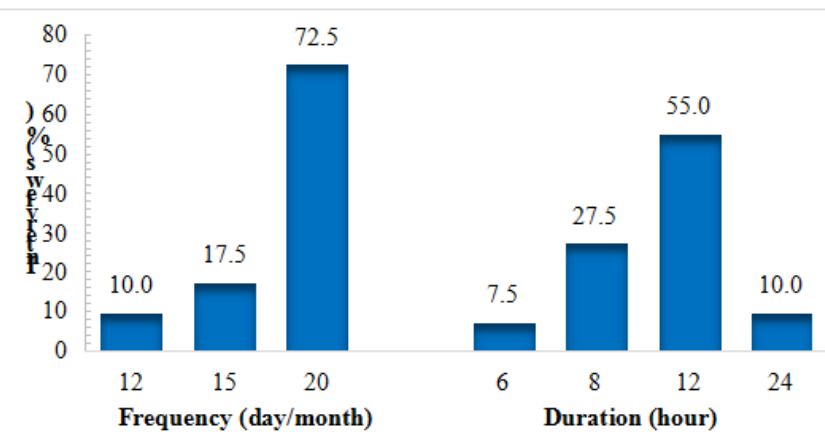

Figure 3. Frequency (A) and duration (B) of fishing

The fishing fleet of the State of Pará uses several items in its fisheries, such as: zagaia, harpoon, net, lines, trawls, matapi, longlines and waiting net (mesh). The net, the longline and the matapi are the most used fishing gear, varying only in terms of the size of the devices and the quantity used (CEPNOR, 2006). Figure 4 shows that in Monsarás District, to catch fish, fishermen use more than one type of fishing modality. of the total, $12.5 \%$ fishermen use fixed traps (corral), $26.8 \%$ use mobile nets and $55.3 \%$ use lines with hooks (longline). Depending on the type of fishing modality, small live fish are returned to the sea and those that cannot survive serve as food for fishermen. The caught fish are removed and stored in the canoes.

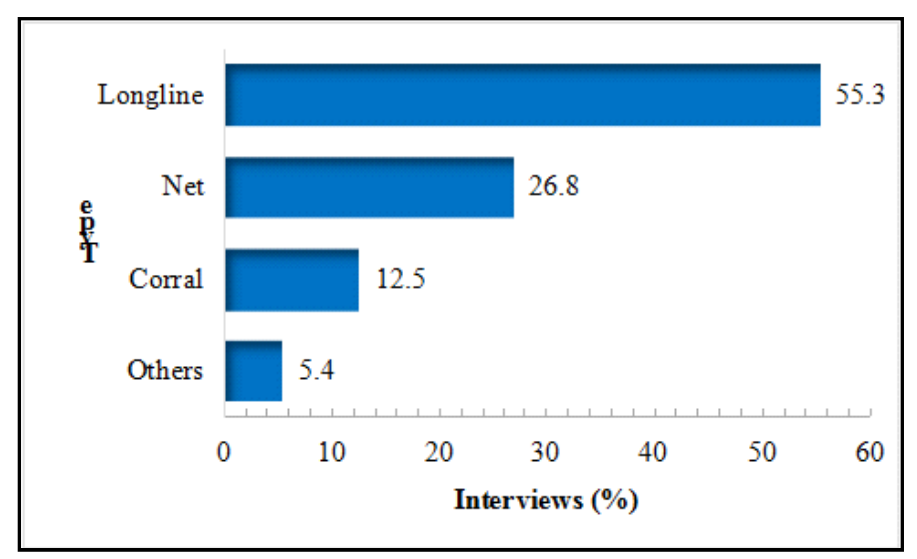

Figure 4. Type of fishing modality adopted by fishermen

Fishermen using nets have to buy them and their maintenance is done by the fishermen themselves. It usually measures 30 to 
$80 \mathrm{~m}$ in length and $2.0 \mathrm{~m}$ in height. The mesh size varies between 25 to $40 \mathrm{~mm}$, depending on the target species. Nets are used throughout the year, both for waiting and trawl nets. The longline is formed by a main line (mother) and secondary lines (handles), both attached to the hooks. In the hand line (term used by the fishermen of Monsarás) the hooks are tied by fathoms and spaced ("breasts") with about one meter. The hooks are "broken", that is, tied in a nylon thread to be attached to the main line. The type of longline practiced in Monsarás is the surface where it leaves the hooks adrift on the high sea supported by buoys. These buoys are made with PET bottles (found in the city garbage and taken from the Marajó Bay) tied to an iron rod.

In the State of Pará, rowing and sailing vessels predominate, representing $68.8 \%$ of the Pará fleet. What gives the continental fishing sector of the State of Pará an eminently artisanal character, even though larger motorized vessels also operate in inland waters (CEPNOR, 2006). In Salvaterra and Soure, on Marajó Island, the most used boats are Small Boats (BPP), Mounts (MONT) and Motorized Canoes (CEPNOR, 2006). In the District of Monsarás, as shown in Figure 6, the type of boat most used by $75.1 \%$ fishermen is the motorized canoe, $11.4 \%$ use the motor boat and the others mount (boat and hull). The mounts are rowing by one or two fishermen and do not have the autonomy to fish large quantities, so they are usually lent to fishermen who just want to fish for their own consumption. The boats of $67.5 \%$ of fishermen have safety equipment such as vests and buoys. As for the maximum capacity of fish per boat, $29.5 \%$ fishermen claim that they fish in boats with a maximum capacity of $2,000 \mathrm{~kg}$ and $25.0 \%$ have boats with a capacity of $1,000 \mathrm{~kg}$. Boats with a capacity of 200 $\mathrm{kg}, 300 \mathrm{~kg}$ and $500 \mathrm{~kg}$ are used by only $2.3 \%$ fisherman each and depending on the maximum capacity of each boat the production can reach up to two tons and are transported by motor-powered canoes. When they reach the igarapé, the fish are placed in baskets. All production is used, since there is no fish disposal. Fishermen's work and production relations in Monsarás are called "fishing from afar" according to Nogueira (2005), that is, fishermen use traditional fishing methods, have kinship ties and their activities are done through a partnership system . The partnership system (or distribution system as it is called by the fishermen in Monsarás) is formed by fishermen whose income is obtained from the division of fish production. The system works by dividing the fish caught among the fishermen in equal parts, plus the boat. However, before the division, a part of the catch of the fish is divided among the fishermen for their own consumption.

According to the CEPNOR (2006), the caught fish is marketed whole and gutted, with rare exceptions. In the Monsarás District, $90 \%$ of fishermen sell fish within the municipality directly to the consumer or through the local middlemen. In the district there is only one middleman, who is responsible for buying the fish, conserving it and selling it at the Ver-o-peso market in the capital. Fishermen who sell fish with the middlemen do not have financial resources and their own boats equipped. The $10 \%$ of fishermen who sell fish in Ver-o-peso have vessels suitable for this type of marketing. The diversity of aquatic species found on the island is due to the area of the sea coast of the Marajo archipelago having a large amount of nutrients discharged by the Amazon River in the Atlantic Ocean (PDTSAM, 2007). On the other hand, few species are commonly caught, and, according to $90.0 \%$ fishermen, the dorado is the most caught species followed by yellow hake and young (cited by only one fisherman). Despite the great variety of species in the region, in Monsarás only three are the most caught due to their commercial value and the type of capture method most used, the longline. This is because in this modality both the size of the hook and the bait are chosen according to the type of target species. Failure to capture other species that exist in the archipelago may be associated with seasonality and the efficiency of capture of the fishing oil (PDTSAM, 2007).

The fish with the greatest commercial value is the young, followed by yellow and golden hake. Since the bream is the species that has the easiest capture, according to $90 \%$ of fishermen. One of the least profitable species is mackerel, since its school is more abundant. The price of fish can vary and this happens in three moments: the first when there is a shortage of fish (production decreases and the price increases); the second, during Holy Week, when the demand for fish is greater and the fishermen take the opportunity to increase prices; and the third, when the fish is noble, in the case of the young. As for knowledge and compliance with environmental laws in the region, $97.5 \%$ of fishermen stated that this environmental knowledge refers only to Defeso Seguro and the fulfillment of government requirements for receiving the benefit. Even knowing the Law of the Defeso, only $50 \%$ of the fishermen obey the time foreseen in law in the Island of Marajó, that happens between the months of January and April. Of the 40 respondents, $90 \%$ said they received insurance. The four fishermen $(10 \%)$ who do not receive do not have the minimum time required to contribute to the INSS (Figure 5A). Of the total, 36.1\% fishermen have already received insurance between one and five years, $55.6 \%$ have received it for six and 10 years and only $8.3 \%$ have received it for more than a decade (Figure 5B).
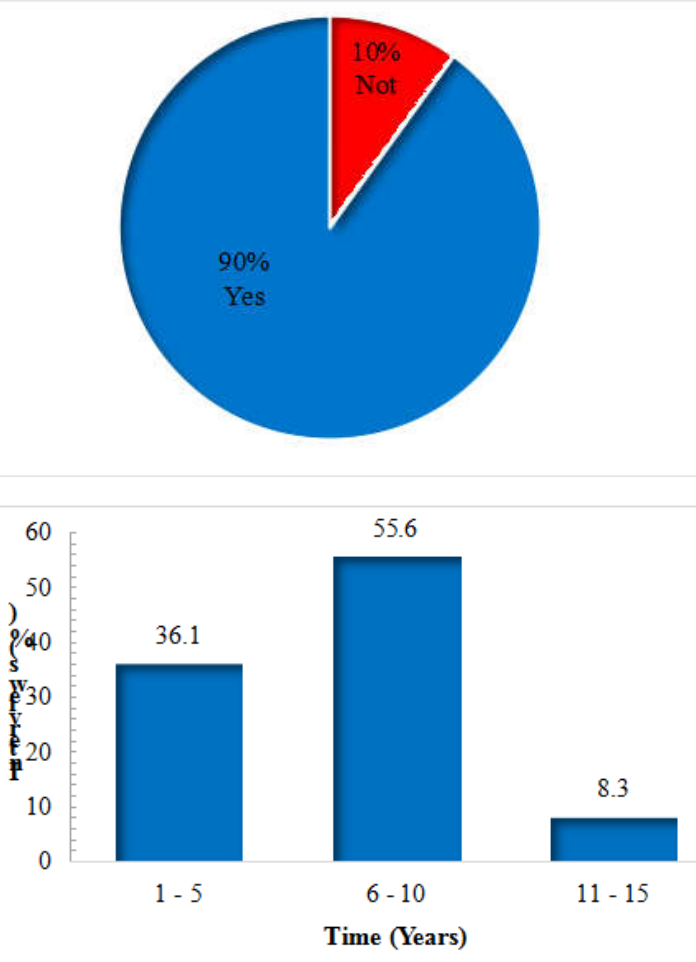

Figure 5. Receipt (A) and time (B) that fishermen have about Defeso Seguro

What is observed in Monsarás is consistent with the reality of the Brazilian fisheries policy in which, according to Isaac and 
Mota (1993), conventional management has a range of tools, including prohibitions during the spawning period and which, despite fishing licenses mandatory for all commercial fishermen, there are no restrictions on the number of fishermen who can exploit the fishing resource. In contrast, the MPA (2011) states that professional artisanal fishermen have a fundamental role in the sustainable development of the country, not least because it is from the sea, rivers and lakes that they get their food and income. Thus, in accordance with the researched literature and through on-site observations, there is no evidence that the fishing activity in Monsarás impacts the aquatic environment, since the boats and oil used are of handcrafted characteristics. Even though artisanal fishing is an activity that requires few fishing gear, small vessels and low environmental impact, fishermen in the District of Monsarás demonstrate the need for larger vessels, increased fishing production, greater availability of financial investment and more in-depth knowledge of the environmental laws.

\section{Final Considerations}

Artisanal fishermen have a fundamental role in the sustainable development of a region and the fishing activity in Monsarás is predominantly artisanal, characterized by petrechos and small boats. Two or more types of fishing methods are used to catch the fish (longline, net and corral) and, depending on the type of modality, small live fish are returned to the sea and those that cannot survive serve as food for fishermen. . Longline is a type of sport that favors this type of action. As it is an activity that produces a limited amount of fish, the sale takes place directly to the consumer and only one intermediary works on the spot. The commercial value is determined by the quality given to certain species by the market itself, as is the case with the offspring, but also by the volume commonly captured, which reduces the commercial value, as is the case with bream and yellow hake. And in the case of mackerel, which offers greater abundance of schools for capture, the commercial value further restricts profitability for the fisherman. Despite the advantages that artisanal fishing provides, this activity is greatly affected by cyclical issues related to social conditions and fishing infrastructure. These issues deserve special attention from the Public Power in the search for solutions in order to value the fisherman, improve artisanal fishing and increase the production of fish in the District of Monsarás.

\section{REFERENCES}

ABREU, J. S.; DI BENEDITTO, A. P. M.; MARTINS, A. S.; ZAPPES, C. A. Pesca artesanal no município de Guarapari, estado do Espírito Santo: Uma abordagem sobre a percepção de pescadores. Society \& Nature, v. 32, p. 59-74, Feb 42020.

CAJADO, D. M.; MEIRELES, A. J. A.; Casimiro Filho, F. Estudo bibliométrico das produções cientícas sobre economia ecológica, multifuncionalidade da agricultura e pesca artesanal. sinergia - Magazine of the Institute of
Economic, Administrative and Accounting Sciences, Rio Grande, Rio Grande do Sul, Brazil., V. 24, n. 1, p. 65-72, abr. 2020. ISSN 2236-7608.

CEPNOR - CENTRO DE PESQUISA E GESTÃO DE RECURSOS PESQUEIROS DO LITORAL NORTE. Structural census report on continental waters fisheries in the northern region. Ministry of National Integration. Amazon Development Agency. Federal Rural University of the Amazon. Health insurance ADA/UFRA $\mathrm{N}^{\mathrm{o}}$ 018/2004. Belém - Pa. 2006.

ISAAC, V. R; MOTA, V. S. Some considerations about piracema legislation and other fishing restrictions in the Middle Amazon. In: FURTADO, L ; MELO, A; LEITÃO, W. Peoples of the Waters: Reality and Perspective in the Amazon. P. 187-211. Museum Paraense Emilio Goeldi, Belém, PA. 1993.

IBGE. Instituto Brasileiro de Geografia e Estatística. Censo 2010. Available in: <http://www.ibge.gov.br/cidadesat/ topwindow.htm?1>. Accessed on: 17 feb. 2012.

ISAAC, V. J; SANTOS, R. V. E; SILVA, B. B; CASTRO, E; SENA, A. L. Diagnosis of fishing on the coast of the state of Pará. In: ISAAC, V. J; MARTINS, A. S; HAIMOVICI, M; ANDRIGUETTO, J. M. Marine and estuarine fisheries in Brazil at the beginning of the 21st century: resources, technologies, socioeconomic and institutional aspects. P. 11-40.Millennium Institutes. RECOS Project. Federal University of Pará. 2006.

MPA - MINISTÉRIO DA PESCA E AQUICULTURA. Artisanal Fishing. Available in: <http://www.mpa.gov.br/ \#info-estatistica/estatistica-da-pesca-e-aquicultura $>$. Accessed on: 26 Dec. 2011.

MIRANDA, M. C. C. Sedimentology, stable isotopes and palynology of quaternary deposits in the east of the island of Marajó, state of Pará. Thesis. University of Sao Paulo. Institute of Geosciences. 233p. University of Sao Paulo. Sao Paulo. 2010.

NOGUEIRA, C. S. Fishing territory in the Marajoara estuary: black rural communities and conflict in the municipality of Salvaterra - Pará. Dissertation. Graduate Program in Sustainable Development of the Humid Tropic. Center for High Amazon Studies. Federal University of Pará. 2005.

PEIXOTO, L. B. L. Salvaterra and the role of watercourses in a changing context. Article. In: II Meeting of the Brazilian Society of Sociology in the Northern Region. 18 p. Belém, PA. 2010.

PDTSAM - PLANO DE DESENVOLVIMENTO TERRITORIAL SUSTENTÁVEL DO ARQUIPÉLAGO DO MARAJÓ. Federal government. Government of the State of Pará.313 p. 2007.

SANTOS, M. A. S The productive chain of artisanal fisheries in the state of Pará: a case study in northeastern Pará. Amazonia: Cia \& Desenvolvimento.. v,1. nº 1. Belém, PA. p. 61-81. 2005 . 